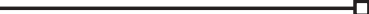

Expansive clay is one of the problems in construction work. The soil has the characteristics of being easy to expand when exposed to water, causing a decrease in the strength value of the soil. The can be overcome by stabilizing the soil. The soil is formed from weathering and contains the mineral montmorillonite. The soil is very sensitive to moisture content, has a high shrinkage rate, thus interfering in construction work. Therefore, additional materials are needed to overcome the problem, one of which is soil stabilization. The study aimed to stabilize the expansive clay soil. This is done by analyzing the physical and mechanical properties of expansive clay with a shell ash mixture. Expansive clay is taken directly (undisturbed) or disturbed. Undisturbed soil is taken using a tube, so that the soil is not disturbed by outside air, while disturbed soil is taken using a shovel and then put into a sack container. Expansive clay stabilization method lies in adding the percentage of shell ash mixture $(5 \%, 10 \%, 15 \%$, and $20 \%)$. The soil, the initial moisture content $(\gamma d)$ of which has been determined, is mixed, then molded into a cylindrical shape. The mold was stored in a desiccator, then watered with $5 \%$ water every day until the soil became saturated. Then, using a Proctor test, chemical tests (soil chemical test, soil mineral test), physical tests (soil moisture, Atterberg limit), and mechanical tests (unconfined compression test, compaction test, swelling test) were carried out. The results showed that the addition of an oyster shell ash stabilizing agent to expansive clay affected the physical and mechanical properties of the soil. The addition of shell ash can reduce soil moisture with various plasticity indexes. While the soil stress value decreased, the swelling of the soil increased significantly above the original soil

Keywords: expansive clay, shell ash, soil stabilization, swelling 3D, disturbed soil, undisturbed soil

\section{ANALYSIS OF SOIL CHARACTERISTICS ON EXPANSIVE CLAY STABILIZATION USING SHELL ASH}

\author{
Agus Tugas Sudjianto \\ Corresponding author \\ Associate Professor* \\ E-mail: agustugas@widyagama.ac.id \\ A j i Suraji \\ Associate Professor* \\ Sugeng Hadi Susilo \\ Doctor of Mechanical Engineering \\ Department of Mechanical Engineering \\ State Polytechnic of Malang \\ Soekarno Hatta str., 9, Malang, \\ East Java, Indonesia, 65141 \\ *Department of Civil Engineering \\ University of Widyagama Malang \\ Borobudur str., 35, Malang, \\ East Java, Indonesia, 65142
}

Received date 19.10.2021 Accepted date 27.11.2021 Published date 21.12.2021
How to Cite: Sudjianto, A. T., Suraji, A., Susilo, S. H. (2021). Analysis of soil characteristics on expansive clay stabilization using shell ash. Eastern-European Journal of Enterprise Technologies, 6 (6 (114)), 58 -64. doi:https://doi.org/10.15587/1729-4061.2021.245533

\section{Introduction}

Expansive clay is one of the problems in construction work. This soil is formed from weathering and contains high montmorillonite minerals. Soil is very sensitive to moisture content, has a high shrinkage rate, thus interfering with construction work. For urban areas, the land is getting narrower so that the need for land under any conditions is used for construction. Therefore, additional materials are needed to overcome these problems, one of which is the need for soil stabilization. Several researchers have carried out the process of soil stabilization.

Soil is the basis of building structures such as building foundations, roads, dams, embankments and others. Damage that occurs to roads and buildings, such as lifting or lowering of a foundation, cracks in building walls, and bumpy road surfaces is due to problems with the soil under the building structure. This land problem is not only limited to settlement, but includes shrinkage and land development. Therefore, the chemical, physical and mechanical properties related to the subgrade must be considered, so that the structure of the building above it is stable against the influence of the soil. One type of soil that requires stabilization before being used as the basis for building construction is expansive clay. Because this type of soil has high fluctuations in swelling and shrinkage and contains minerals that have a high swelling potential when exposed to water. So that special handling is needed for this soil stabilization.

Several researchers have conducted research on the stabilization of expansive clay using various materials. [1] states that soil stabilization methods are divided into two categories, namely: mechanical stabilization and chemical stabilization. Mechanical stabilization is the process of improving soil properties by changing its gradation. Meanwhile, chemical stabilization changes the physico-synthetic makeup around and inside the clay particles. [2] stated that soil compaction is very effective for expansive soil stabilization. But it can increase the swell potential of the soil due to the decrease in soil permeability. 
[3] conducted an experimental study of expansive soil stabilization using steel slag (SS). Experiments were conducted to evaluate the effect of steel slag on improving the engineering properties of expansive clay. A series of tests were made to measure the limit of consistency, free swell index, compaction parameters, and free compressive strength of natural and stable soils. Comparing the results obtained for natural soils and stable soils revealed that SS had a significant influence on the strength parameters and considerably increased plasticity and expansion properties. The addition of SS into the soil increases the dry density and reduces the optimum moisture content and increases the free compressive strength. [4] conducted a study on the stabilization of expansive soils by controlling adverse volume changes due to swell-shrink behavior. Lime, cement, $\mathrm{CaCl}_{2}$, fly ash, pond ash, and other chemical reagents have been effective in stabilizing the expansive soil and improving its properties. However, there is no research on soil stabilization using shell ash. Meanwhile, shellfish waste is very common on the beach. Referring to the statement above, the stability of the soil can be improved by adding some elements that strengthen the soil. Therefore, studies that are devoted to determining the effect of shell ash mixture on expansive clay related to chemical, physical and mechanical properties as a soil stabilizer are of scientific relevance.

\section{Literature review and problem statement}

[5] said that soil alkalinity can improve soil stabilization. The results of electron analysis (SEM-EDX) showed that the new cement compound was formed, the weak soil structure was dispersed into a strong flocculation structure. In addition, increasing the concentration of LS and $\mathrm{NaCl}$ causes the plastic limit to increase and the liquid limit to decrease so that the plasticity index decreases. So that the lime sludge activated by $\mathrm{NaCl}$ has a positive effect on soil properties. [6] stated that the addition of iron oxide to the expansive clay can improve the stability of the soil as a road base. [7] found that the combination of lime and pozzolana affected increasing the cohesion and internal friction of the soil. The combination of lime and pozzolana produces higher shear strength parameters than expansive clay. [8] found that limestone is effective in stabilizing high-plasticity clays and expansive clays. It is evidenced by the increase in the results of the unconfined compression test, and the liquid limit value decreased and the plastic limit value increased.

[9] studied the effect of using high-density polyethylene as a stabilizer on the structure and properties of geotechnical clay. The results show that the polymer significantly improves the physical properties of the expansive clay. [10] studied mixing of expansive clay with bagasse and lime ash. The mixture of bagasse ash and lime increased the CBR value of the soil, while the swelling value and free development value decreased.

Expansive clay is soil that has a high level of sensitivity and shrinkage properties that can cause damage to buildings that stand on it. Because it has a very high potential to expand and shrink by changes in soil moisture [11].

Clay is an aggregate with microscopic and submicroscopic-sized particles that are plastic, with moderate to high water content. The permeability of clay is very low. The size of the clay minerals $(0.002 \mathrm{~mm}$, and finer) overlaps somewhat with the size of the silt. Clay minerals consist of three important components, namely montmorillonite, illite, and kaolinite. The mineral montmorillonite has a larger surface area and is very easy to absorb large amounts of water when compared to other minerals so that soils that have sensitivity to the influence of water are very easy to expand [12]. The more water that is absorbed, the more the volume of the soil increases. Changes in volume can damage the strength of the building structure that occupies the land. Expansive clay is also known as swelling soil, which is a great shrink-swell phenomenon due to changes in moisture in the clay.

Soil stabilization in general is a process to improve soil properties by adding materials to the soil, to increase soil strength and maintain shear strength. In addition, volume stability, strength or bearing capacity, permeability, and durability or durability [11].

[13] used bagasse ash as a soil stabilization mixture. Bagasse ash is mixed with asphalt as the base material because the mixture is specially formulated to increase durability and fatigue. Serves as a foundation layer under the surface layer, a binder that has been compacted and placed on top of the sub-base layer and serves to support, spread the load and harden the surface layer. [14] conducted a study on the stabilization of expansive clay with table salt $(\mathrm{NaCl})$. A mixture of table salt $(\mathrm{NaCl})$ as a soil stabilizer can reduce moisture, PI (plasticity index), and increase soil density. As well as react to replace and form soil grains. The addition of table salt $(\mathrm{NaCl})$ causes a decrease in the value of soil development and an increase in the CBR value of the soil.

[15] investigated the effect of brick dust on the stability of expansive clays. The results showed that there was a decrease in linear shrinkage and an increase in the Atterberg limit of the soil. [16] used sand to stabilize expansive clay. The addition of sand aims to reduce the ratio of the cohesive properties of the clay, increase the density value, reduce the potential for soil development and decrease soil permeability. The results obtained indicate that the greater the sand content, the lower the plasticity, moisture content, and expansion properties of the soil. [17] used the deep soil mixing method by adding lime to increase the stabilization of the expansive clay. As a result, the addition of lime can increase the strength of the soil. [18] used industrial and agricultural wastes as additives for stabilizing expansive clays. The result is that the use of industrial and agricultural wastes can increase compatibility and compressive strength and reduce the plasticity index. [19] used sugarcane straw ash and polypropylene fibers as expansive clay stabilizers. This research used a compression test and a California bearing test, using variations in the percentage of sugarcane straw ash and polypropylene fibers. The use of sugarcane straw ash and polypropylene fiber can increase the UCS and CBR values. [13] conducted research on expansive clay stabilizers using quicklime. The study used the compressive strength test. The results showed that dolomite lime was more effective than calcite lime.

[20] stated that the addition of eggshell powder to the expansive soil increased from $5 \%$ to $20 \%$. After adding eggshell powder, linear shrinkage decreased by $10 \%$ after 28 days, the maximum dry density of the expansive soil decreased from $1.323 \mathrm{~g} / \mathrm{cm}^{3}$ to $1.293 \mathrm{~g} / \mathrm{cm}^{3}$. In addition, there was an increase in geotechnical characteristics after adding $5 \%$ eggshell powder, compressive strength at collapse and strain increased by $18 \%$ and $9 \%$, compared to expansive soil without treatment. While the combination of eggshell flour and lime can increase the compressive strength of soil by $20 \%$, and decrease linear shrinkage by $10.7 \%$ after 7 days. In addition, the combination of lime (5\%) and eggshell powder (5\%) can induce about $15 \%$ buildup in compressive strength. While the CBR value of the soil increased from $2 \%$ 
to $56 \%$ when combined with the optimal additive value. Utilization of eggshell powder for expansive soil stabilization without or with lime combination not only improves the geotechnical properties of expansive soils, but also helps to minimize the side effects of this domestic waste on the environment.

From several studies related to the stabilization of expansive clays, there have been no studies using waste materials with high calcium content (such as shell ash) to improve the properties of expansive clays, both strength and shear resistance of the soil. Therefore, it is necessary to conduct research on the chemical, physical and mechanical properties of shells as a stabilizer of expansive clay.

\section{The aim and objectives of the study}

The study aims to stabilize the bearing capacity and shear stress of low expansive clay by mixing with shell ash. It is to stabilize the construction ground.

To achieve the aim, the following objectives were set:

- to determine the effect of adding shell ash on the chemical composition of expansive clay;

- to determine the effect of adding shell ash on the physical and mechanical properties of expansion clay.

\section{Materials and methods}

Expansive clay is taken directly, located in Jombang, East Java-Indonesia. Undisturbed soil samples were taken using a sample tube, with the aim that the soil is not disturbed by outside air, while disturbed soil samples were taken using a shovel and put into a container.

To get clam shell ashes is to burn the clam shells at a temperature of $250-300{ }^{\circ} \mathrm{C}$ for $\pm 1-2$ hours. Then the clam shells that have been in the oven are mashed by pounding or with a grinding machine until the mussels become powder and pass the No. 40 sieve, before that the shells are cleaned and rinsed with clean water.

Furthermore, the expansive clay is mixed with stabilizing material (shell ash) with the composition of the mixture being: $95 \%$ clay $+5 \%$ added material, $90 \%$ clay $+10 \%$ added material, $85 \%$ clay $+15 \%$ added material, soil $80 \%$ clay $+20 \%$ added material. The soil, the initial moisture $\left(\gamma_{d}\right)$ of which has been determined, is mixed, then molded into a cylindrical shape. The mold was stored in a desiccator, then watered with $5 \%$ water every day until the soil became saturated. Then, using a Proctor test, chemical tests (soil chemical test, soil mineral test), physical tests (soil moisture, Atterberg limit), and mechanical tests (unconfined compression test, compaction test, swelling test) were carried out. The research is carried out as shown in Fig. 1.

Fig. 1 shows the research flow starting from the preparation of expansive clay samples and shell ash. In this study, variations in the added material of oyster shell ash started from $5 \%, 10 \%$, $15 \%$ and $20 \%$. After that, ripening was carried out for 14 days, then chemical, physical and mechanical testing of the soil was carried out. Furthermore, the test results were analyzed and discussion of research results was conducted.

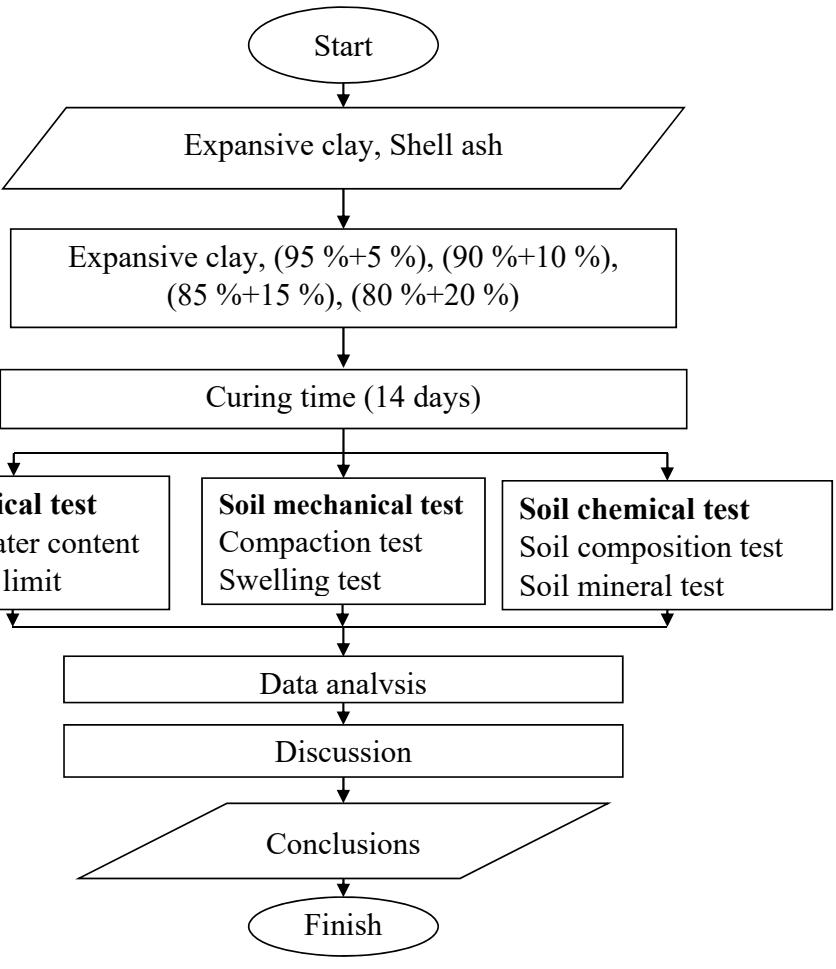

Fig. 1. Research flowchart

\section{Research results of stabilization of expansive clay using shell ash}

\section{1. Chemical test}

Chemical testing includes soil chemical composition test, and soil minerals test.

This test was conducted to determine the composition of the soil and soil-forming elements:

1. Soil chemical composition. The method of testing the chemical composition is carried out by X-ray testing. The results of testing the chemical composition are given in Table 1.

Table 1

Chemical composition of soil

\begin{tabular}{|c|c|c|c|c|c|}
\hline \multirow{2}{*}{ Element } & \multicolumn{5}{|c|}{ Weight percentage (\%) } \\
\cline { 2 - 6 } & Expansive clay & $5 \%$ & $10 \%$ & $15 \%$ & $20 \%$ \\
\hline $\mathrm{SiO}_{2}$ & 33.42 & 33.26 & 36.82 & 40.41 & 42.65 \\
\hline $\mathrm{Al}_{2} \mathrm{O}_{3}$ & 8.3 & - & 5.1 & 5.5 & 4.9 \\
\hline $\mathrm{Fe}_{2} \mathrm{O}_{3}$ & 37.53 & 40.81 & 41.34 & 33.79 & 35.13 \\
\hline $\mathrm{TiO}_{2}$ & 2.33 & 2.25 & 2.29 & 2.13 & 2.11 \\
\hline $\mathrm{CaO}$ & 2.43 & 8.56 & 8.18 & 8.00 & 8.10 \\
\hline $\mathrm{K}_{2} \mathrm{O}$ & 0.62 & 1.0 & 1.43 & 1.72 & 2.34 \\
\hline $\mathrm{V}_{2} \mathrm{O}_{5}$ & 0.12 & 0.14 & 0.13 & 0.13 & 0.11 \\
\hline $\mathrm{Cr}_{2} \mathrm{O}_{3}$ & 0.048 & 0.095 & 0.089 & 0.085 & 0.083 \\
\hline $\mathrm{MnO}$ & 1.36 & 1.6 & 1.4 & 1.3 & 1.3 \\
\hline $\mathrm{NiO}$ & 1.34 & 1.76 & 1.55 & 1.46 & 1.50 \\
\hline $\mathrm{CuO}$ & 0.26 & 0.33 & 0.30 & 0.29 & 0.30 \\
\hline
\end{tabular}

Table 2 shows the test results of the chemical composition of the expansive clay sample and the soil that has been added to shell ash. There are some chemical elements whose content is getting smaller $\left(\mathrm{K}_{2} \mathrm{O}, \mathrm{TiO}_{2}\right.$, and $\left.\mathrm{Al}_{2} \mathrm{O}_{3}\right)$ but other elements are getting bigger. 
The test results of the chemical composition of shells are shown in Table 2.

Table 2

Chemical composition of shells

\begin{tabular}{|c|c|c|}
\hline \multirow{2}{*}{ Element } & \multicolumn{2}{|c|}{ Heating temperature } \\
\cline { 2 - 3 } & $500{ }^{\circ} \mathrm{C}$ & $700{ }^{\circ} \mathrm{C}$ \\
\hline $\mathrm{SiO}_{2}$ & 0.24 & 0.15 \\
\hline $\mathrm{Al}_{2} \mathrm{O}_{3}$ & 0.04 & 0.06 \\
\hline $\mathrm{Fe}_{2} \mathrm{O}_{3}$ & 0.37 & 0.46 \\
\hline $\mathrm{CaO}$ & 54.43 & 55.1 \\
\hline $\mathrm{MgO}$ & 0.85 & 0.1 \\
\hline $\mathrm{Na}_{2} \mathrm{O}$ & 0.00 & 0.1 \\
\hline $\mathrm{K}_{2} \mathrm{O}$ & 0.01 & 0.01 \\
\hline $\mathrm{TiO}_{2}$ & 0.09 & 0.09 \\
\hline $\mathrm{MnO}^{2} \mathrm{O}$ & 0.07 \\
\hline $\mathrm{P}_{2} \mathrm{O}_{5}$ & 0.06 & 0.02 \\
\hline $\mathrm{SO}_{3}$ & 0.02 & 0.00 \\
\hline $\mathrm{H}_{2} \mathrm{O}$ & 0.08 & 0.21 \\
\hline $\mathrm{HD}$ & 0.04 & 43.22 \\
\hline
\end{tabular}

From the results of the analysis of the chemical composition, the shell ash dominantly contains $\mathrm{CaO}$. So that it can be used as a lime substitute in soil stabilization.

2. Soil minerals. The results of soil mineral testing are shown in Table 3.

Table 3

Mineral composition of soil

\begin{tabular}{|c|c|c|c|c|c|}
\hline \multirow{2}{*}{ Mineral } & \multicolumn{5}{|c|}{ Mix composition } \\
\cline { 2 - 6 } & Expansive clay & $5 \%$ & $10 \%$ & $15 \%$ & $20 \%$ \\
\hline Montmorilonite & 40.38 & 38.98 & 35.11 & 36.88 & 33.86 \\
\hline Halloysite & 15.71 & 10.41 & 15.32 & 17.18 & 16.09 \\
\hline Feldspar & 11.34 & 24.12 & 24.36 & 25.54 & 26.32 \\
\hline Alpha quartz & 9.97 & 15.87 & 13.23 & 10.43 & 12.95 \\
\hline Cristobalite & 21.65 & 10.51 & 11.21 & 10.35 & 11.61 \\
\hline
\end{tabular}

Table 4 shows the mineral content of the soil in the expansive clay with a soil sample that has been added to shell ash. There was a decrease in the mineral content of Montmorillonite, Halloysite and Cristobalite. Meanwhile, the mineral content of Feldspar and Alpha quartz is getting bigger.

\section{2. Physical and mechanical properties test}

Soil physical testing includes soil properties, soil water content, and Atterberg test. This test is to better understand the physical properties related to what category it belongs to and to determine the composition of the soil and soil-forming elements:

1. Properties of expansive clay.

Test results of the physical properties of the soil used as research material are shown in Table 4.

From the results of the stiffened test, the results obtained from the results of the analysis of size analysis, consistency limits, specific gravity, moisture.

2. Soil moisture. The moisture test showed that the addition of shell ash stabilizing agent reduced the moisture content as shown in Fig. 2.
Table 4

Properties of expansive clay

\begin{tabular}{|c|c|c|}
\hline \multicolumn{2}{|c|}{ Properties } & Content \\
\hline \multirow{4}{*}{ Granule size } & Passed No. 200 ( \%) & 76 \\
\hline & Passed $<0.15 \mathrm{~mm}(\%)$ & 88.6 \\
\hline & Passed $<0.3 \mathrm{~mm}(\%)$ & 91.2 \\
\hline & Liquid limit (\%) & 88.19 \\
\hline \multirow{2}{*}{ Consistency limit } & Plastic limit ( \%) & 39.46 \\
\hline & Plasticity index $(\%)$ & 48.73 \\
\hline \multicolumn{2}{|c|}{ Specific gravity (Gs) } & 2.65 \\
\hline \multicolumn{2}{|c|}{ Moisture (0\%) } & 39.60 \\
\hline \multicolumn{2}{|c|}{ Activity (A) } & 1.287 \\
\hline
\end{tabular}

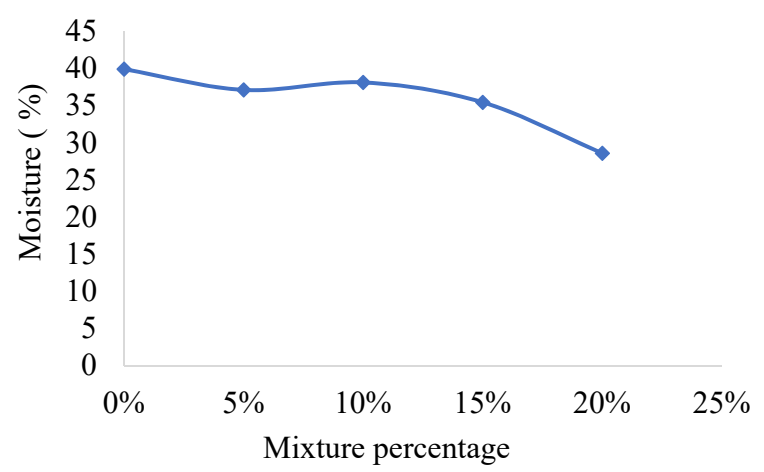

Fig. 2. Moisture content of mixed expansive clay

Fig. 2 shows that the greater the percentage of the ash mixture, the lower the moisture value. When the native soil is mixed with shell ash by $5 \%$, the soil water content decreases to $37.09 \%$, then at the mixture composition of $10 \%$, the water content rises back to $38.10 \%$, at the mixture composition of $15 \%$, the water content decreases to $35.42 \%$, then in the composition of the mixture $20 \%$, the water content decreases again to $28.57 \%$.

3. Atterberg limit. This test aims to determine the soil plasticity index in the field by conducting the Atterberg limit test, which consists of a liquid limit test and a plastic limit test. The plasticity index value is obtained from the liquid limit value minus the plastic limit value $(\mathrm{PI}=\mathrm{LL}-\mathrm{PL})$, Table 5 .

Table 5

Atterberg limit of soil

\begin{tabular}{|c|c|c|c|}
\hline Composition & $\begin{array}{c}\text { Liquid limit } \\
(\%)\end{array}$ & $\begin{array}{c}\text { Plastic limit } \\
(\%)\end{array}$ & $\begin{array}{c}\text { Plasticity } \\
\text { index (\%) }\end{array}$ \\
\hline Original Soil & 88.00 & 30.00 & 58.00 \\
\hline Mixture 5\% & 77.53 & 31.02 & 46.51 \\
\hline Mixture 10\% & 60.15 & 31.11 & 29.04 \\
\hline Mixture 15\% & 58.18 & 33.33 & 24.85 \\
\hline Mixture 20\% & 57.24 & 39.46 & 17.78 \\
\hline
\end{tabular}

A mixture of shell ash on expansive soils demonstrates a decreasing plasticity index value as shown in Table 5. The more the mixture, the lower the plasticity index value. This shows that the addition of shell ash can reduce the swelling of the expansive soil.

4. Unconfined compression test. An unconfined compression test is a form of test to determine the sensitivity and magnitude of the free compressive strength of the soil. In this test, the holding stress is zero. The axial stress applied to 
the test object relatively quickly reaches failure. The results of the unconfined soil test are shown in Fig. 3.

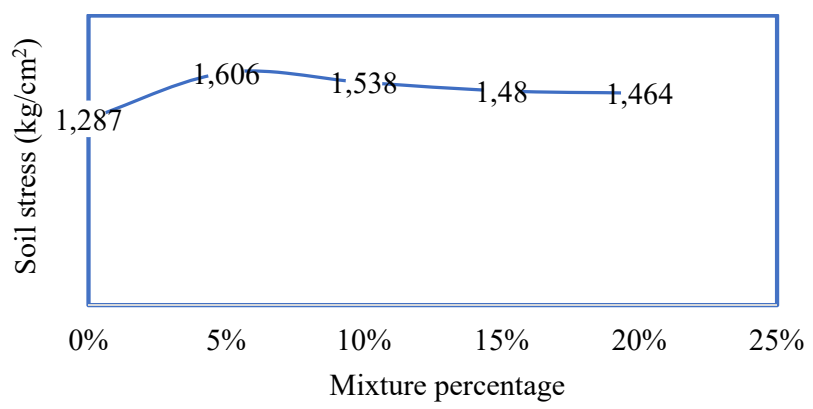

Fig. 3. Unconfined soil stress

Fig. 3 shows the test results for unconfined native soil and a mixture of shell ash above. It shows that the soil stress that occurs is quite variable up and down along with the addition of stabilizing material. At the point of failure, the total minor principal stress is zero. The original soil has a value of $1.287 \mathrm{~kg} / \mathrm{cm}^{2}$. Then the original soil was mixed with $5 \%$ oyster shell ash and the soil stress value increased to $1.606 \mathrm{~kg} / \mathrm{cm}^{2}$. Then for the composition of $10 \%$, the original soil and a mixture of soil stress values slightly decreased to $1.538 \mathrm{~kg} / \mathrm{cm}^{2}$. Then at $15 \%$ mixed soil composition, the soil stress value again decreased to $0.193 \mathrm{~kg} / \mathrm{cm}^{2}$. And in the last mixture composition of $20 \%$, soil stress becomes $1.464 \mathrm{~kg} / \mathrm{cm}^{2}$.

5. Compaction test. A standard compaction test was carried out to obtain the maximum dry weight $\left(\gamma_{d \max }\right)$ and optimum moisture content $\left(W_{\text {opt }}\right)$. Fig. 4 shows the results of the soil compaction test with variations in the mixture of shell ash.

Fig. 4 shows the results of the compaction test. Each parameter of the mixture composition has various values and tends to increase. When compared to native soils, mixed soils increase the soil density. Where the increase in mixed soil density of $15 \%$ is the largest compared to the others. The mixture of $15 \%$ shows that the greater the soil moisture, the denser the soil mixture. This is because the larger the soil pores, the easier the shell ash to occupy the gaps, replacing groundwater. Intersection occurs between the mixture of $15 \%$ and $5 \%$ at $30 \%$ moisture. While the soil moisture is $25 \%$, the mixed soil density is $15 \%$ below the $5 \%$ mixture. This is because the slope of the $5 \%$ mixture is flatter than the $15 \%$ mixture. The next intersection occurs at the soil moisture between $30-35 \%$, between the mixture of $15 \%$ and $20 \%$. In the mixture of $20 \%$, the soil compaction results are unstable as in the mixture of $15 \%$. The mixed soil density of $20 \%$ is high at $30 \%$ soil moisture but after that, it drops to $40 \%$ ground moisture, then it rises again.

The third interference occurs between the mixture of $15 \%$ and $10 \%$ at $35 \%$ ground mois- ture. The mixture of $10 \%$ maximum soil density at $35 \%$ soil moisture then decreases, while the maximum $15 \%$ mixed soil density at $40 \%$ moisture, then only decreases. The fourth intersection occurs at $45 \%$ ground moisture, where the $15 \%$ mixture decreases while the $20 \%$ mixture increases. This occurs due to too high soil moisture so that the ash from the shells needs more to replace groundwater.

6. Swelling 3D soil. Fig. 5. shows the percentage of swelling and pressure when the soil is loaded. There was a significant increase between the original soil and the soil that had been mixed with shell ash. The shell ash mixture soil is almost evenly distributed, and far from the original soil. The increase in soil swelling depends on the curing time.

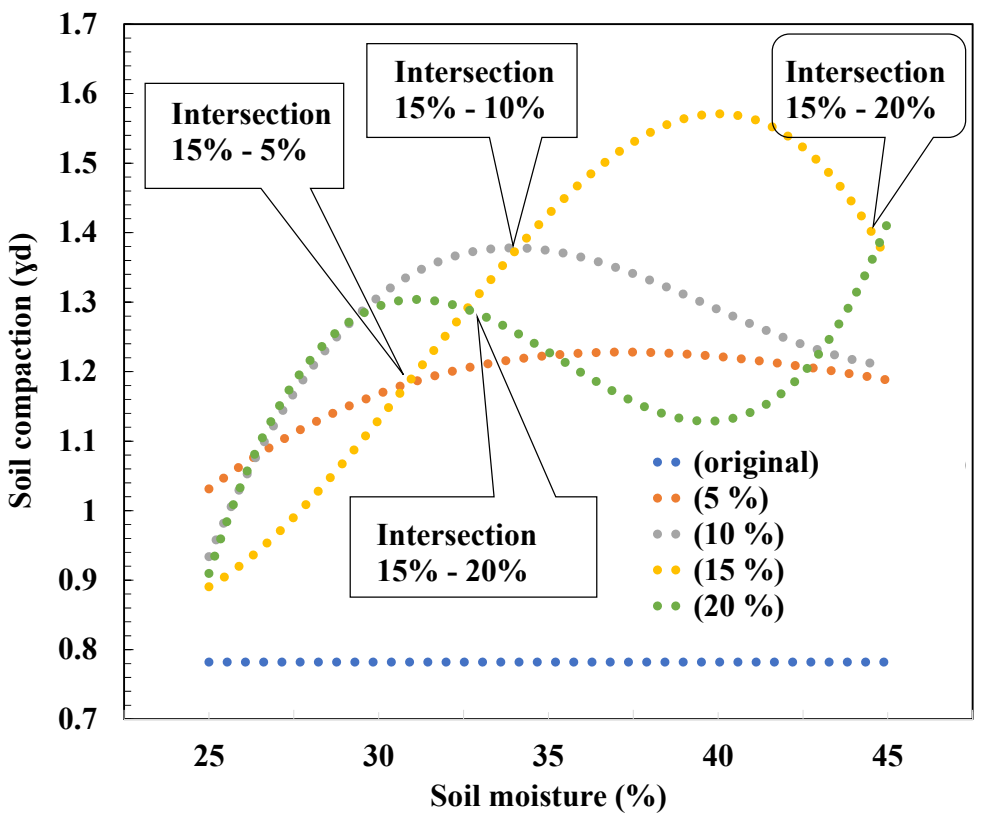

Fig. 4. Relationship between soil moisture versus soil compaction

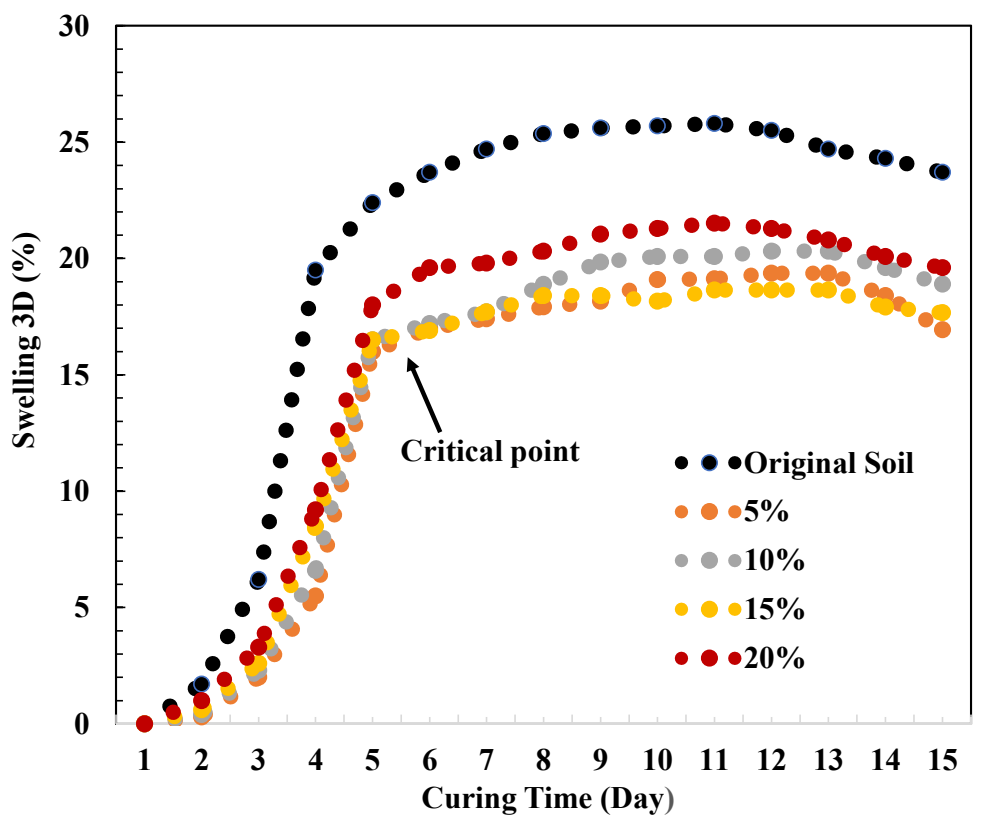

Fig. 5. Relationship of curing time to soil swelling 
Fig. 5 shows the presence of a mixture at seven days of treatment. This is because the shell ash has seeped into the soil and is bound to the soil elements. After seven days, the swelling of the soil increased in each mixture. Because the soil and shell ashes have bonded tightly. The swelling test of the original soil with a composition of $15 \%$ clam shell ash on the first and second days increased by $0.86 \%$ to the value of the diameter of the test object. On the $3^{\text {rd }}$ and 4 th days, the swelling decrease in the diameter of the samples increased to $1.14 \%$. On the 5 th day, the swelling decrease in the diameter of the sample increased to $1.71 \%$. On the 6th day, the swelling decrease in the diameter of the sample increased to $2.57 \%$. On the 7 th and 8 th days, the swelling decrease in the diameter of the samples increased to $3.43 \%$. On the 9 th day, the swelling decrease in the diameter of the sample increased to $3.45 \%$. On the 10th, 11th and 12th days, the swelling decrease value reached the maximum point for the diameter of the test object, which was $4.02 \%$.

\section{Discussion of the research results of stabilization of expansive clay using shell ash}

Based on Table 1, the liquid limit value and the plasticity index value using the AASTHO classification are included in group A-7-5. This soil belongs to the class of loamy soils with ordinary to poor quality as a subgrade material. Based on the percentage value passed the filter No.200, the soil sample above has a percentage greater than $50 \%$. So, based on the USCS classification table, this soil is generally categorized as a fine-grained soil group. This soil belongs to $\mathrm{CH}$, which is inorganic clay with high plasticity. The results of testing the chemical composition of the soil in Table 2 have the effect of adding shell ash. This is because shell ash contains more $\mathrm{CaO}$ elements. Thus hardening the expansive clay, thereby increasing the strength of the soil and its shear stress.

Table 4 shows that the greater the mixture of shell ash can reduce montmorillonite. It can be seen in $20 \%$ of shell ash, the content of montmorillonite is from 40.38 to 33.86 . Decreasing montmorillonite indicates a harder soil because montmorillonite is a subclass of smectite. The montmorillonite clay is not tightly bound so that water can intervene, causing the clay to swell. The water content of montmorillonite varies and its volume increases rapidly when it absorbs water. Montmorillonite swells with the addition of water. Montmorillonite develops much more than other clays because water penetrates the interlayer molecular space and is adsorped simultaneously. The magnitude of the expansion is largely due to the type of exchangeable cations contained in the sample. Also, the addition of shell ash increased the amount of soil feldspar. The increase in feldspar will decrease the plasticity index (PI) and cohesion while the inner shear angle is higher. The mixture that adds the most feldspar is the $20 \%$ mixture.

Fig. 2 shows that the more the mixture of shell ash, the soil moisture decreases. This is due to the more mixture of oyster shell ash, it can shift the moisture of the expansive clay. Thus, the surface of the clay grains loses repulsion force, and cohesion occurs in the grains, increasing the strength of the soil consistency. When $\mathrm{CaO}$ elements with clay minerals or with pozzolanic components such as $\mathrm{SiO}_{2}$ (hydrous silica) react, a strong and hard gel is formed, namely calcium silicate, which binds grains or soil particles. Silica gel reacts by coating and binding clay particles and closing the soil pores. Then water molecules are trapped in the pores of $\mathrm{SiO}_{2}$, the pores of $\mathrm{SiO}_{2}$ will be tightly closed and water molecules will be bound in it. This causes the clay to become dry and hard. With the absorption of clay hydrogen by chemical compounds contained in the shell ash, such as $\mathrm{CaO}, \mathrm{Al}_{2} \mathrm{O}_{3}, \mathrm{MgO}$, and $\mathrm{Fe}_{2} \mathrm{O}_{3}$, it can shift $\mathrm{H}_{2} \mathrm{O}$ from the clay particles.

Meanwhile, related to the Atterberg limit test, with the increase in the percentage of shell ash, the soil classification group changed based on the plastic limit and the plasticity index decreased. Along with the increase in the percentage of addition of clam shell ash, the liquid limit increases. While the plastic limit, with the addition of clam shell ash can increase the value of the plastic limit. The PI value depends on the liquid limit value and the plastic limit value. The addition of shell ash mixture lowers the liquid limit and increases the plastic limit, so the plasticity index will decrease. The value of the plasticity index (PI) greatly determines the classification of the potential for soil development. The greater the plasticity index of the soil and shell ash mixture, the greater the soil development potential. The lower the plasticity index (PI) of the soil and shell ash mixture, the lower the development potential.

The level of soil density is measured from the value of dry volume weight $\left(\gamma_{d}\right)$. The dry volume weight does not change with the increase in moisture. Thus, the soil that has been compacted in the field, and then changes its moisture, then the dry volume weight remains unchanged, as long as the total volume of the soil remains the same. The degree of soil density is measured by its dry volume weight.

Due to dynamic loads, the soil grains are closer to each other as a result of reduced air voids. Clay soil compacted in the right way will be able to provide high shear strength. Because expansive clays containing montmorillonite tend to change in volume. Solid clays have low permeability and these soils do not compact well when they are very wet. When the clay is compacted, it is difficult for water to flow out of the clay pores. The water that does not want to come out of the soil pores makes it difficult for the grains to stick together when compacted. The $15 \%$ shell ash mixture had the highest level of soil compaction. This was related to the ability of the shell ash element to substitute for expansive clay water.

Meanwhile, the limitation of this research is that the mixture used is a maximum of $20 \%$, then the mixture ratio is increased to $50 \%$. In addition, as a stabilizing agent, the level of ash powder is only 40 mesh. Therefore, further research uses a smaller mesh level or a larger mesh size, in order to get an effective mixture for soil stabilization.

\section{Conclusions}

1. Chemical properties of soil. A large increase in shell ash mixture can reduce montmorillonite, a decrease in montmorillonite indicates an increase in soil hardness. Also, the addition of shell ash increased the amount of soil feldspar. Feldspar will decrease the increase in plasticity index (PI).

2. Physical properties of soil. The more the shell ash mixture, the lower the soil moisture, the grain surface loses repulsion, and cohesion occurs in the grains, increasing the soil consistency. In addition, increasing the percentage of shell ash lowers the plasticity index. The lower the plasticity index (PI), the smaller the development potential. While related to soil mechanical properties, the level of soil density is a measure of the value of dry volume weight $\left(\gamma_{d}\right)$. The dry volume weight does not change with humidity. The $15 \%$ shell ash mixture had the highest level of soil compaction. This was related to the ability of the shell elements to substitute for expansive clay water. 


\section{References}

1. Afrin, H. (2017). A Review on Different Types Soil Stabilization Techniques. International Journal of Transportation Engineering and Technology, 3 (2), 19. doi: https://doi.org/10.11648/j.ijtet.20170302.12

2. Hussain, S. (2017). Effect of Compaction Energy on Engineering Properties of Expansive Soil. Civil Engineering Journal, 3 (8), 610. doi: https://doi.org/10.28991/cej-030988

3. Zumrawi, M. M. E., Babikir, A. A.-A. A. (2017). Laboratory Study of Steel Slag Used in Stabilizing Expansive Soil. Asian Engineering Review, 4 (1), 1-6. doi: https://doi.org/10.20448/journal.508.2017.41.1.6

4. Phanikumar, B. R., Ramanjaneya Raju, E. (2020). Compaction and strength characteristics of an expansive clay stabilised with lime sludge and cement. Soils and Foundations, 60 (1), 129-138. doi: https://doi.org/10.1016/j.sandf.2020.01.007

5. Onyelowe, K. C., Onyia, M. E., Nguyen-Thi, D., Bui Van, D., Onukwugha, E., Baykara, H. et. al. (2021). Swelling Potential of Clayey Soil Modified with Rice Husk Ash Activated by Calcination for Pavement Underlay by Plasticity Index Method (PIM). Advances in Materials Science and Engineering, 2021, 1-10. doi: https://doi.org/10.1155/2021/6688519

6. Akula, P., Naik, S. R., Little, D. N. (2021). Evaluating the Durability of Lime-Stabilized Soil Mixtures using Soil Mineralogy and Computational Geochemistry. Transportation Research Record: Journal of the Transportation Research Board, 2675 (9), $1469-1481$. doi: https://doi.org/10.1177/03611981211007848

7. Prasetyo, Y. E., Zaika, Y., Rachmansyah, A. (2018). Pengaruh Penambahan Abu Ampas Tebu dan Kapur Terhadap Karakteristik Tanah Lempung Ekspansif (Studi Kasus : Tanah di Bojonegoro). Rekayasa Sipil, 12 (2), 118-125. doi: https://doi.org/10.21776/ ub.rekayasasipil.2018.012.02.7

8. Seco, A., del Castillo, J. M., Espuelas, S., Marcelino-Sadaba, S., Garcia, B. (2021). Stabilization of a Clay Soil Using Cementing Material from Spent Refractories and Ground-Granulated Blast Furnace Slag. Sustainability, 13 (6), 3015. doi: https:// doi.org/10.3390/su13063015

9. Sofwan, Nurdin, S. (2020). Bearing Capacity Improvement of Expansive Soil: Stabilization with Cement and Iron Oxide Additive. MATEC Web of Conferences, 331, 02005. doi: https://doi.org/10.1051/matecconf/202033102005

10. Noorzad, R., Ta'negonbadi, B. (2020). Volume change behavior of stabilized expansive clay with lignosulfonate. Scientia Iranica, 27 (4), 1762-1775. doi: https://doi.org/10.24200/sci.2018.50210.1575

11. Lakshman Teja, S., Shraavan Kumar, S., Needhidasan, S. (2018). A Review and Study on Stabilization of Expansive Soil Using Brick Dust. International Journal of Pure and Applied Mathematics, 119 (17), 1999-2005. Available at: https://www.acadpubl.eu/ hub/2018-119-17/2/166.pdf

12. Firoozi, A. A., Guney Olgun, C., Firoozi, A. A., Baghini, M. S. (2017). Fundamentals of soil stabilization. International Journal of Geo-Engineering, 8 (1). doi: https://doi.org/10.1186/s40703-017-0064-9

13. Kojima, T. (2007). Soil Stabilization with Lime. Journal of the Society of Inorganic Materials, Japan, 14 (329), 255-260. doi: https://doi.org/10.11451/mukimate2000.14.255

14. Han, S., Wang, B., Gutierrez, M., Shan, Y., Zhang, Y. (2021). Laboratory Study on Improvement of Expansive Soil by Chemically Induced Calcium Carbonate Precipitation. Materials, 14 (12), 3372. doi: https://doi.org/10.3390/ma14123372

15. Blayi, R. A., Sherwani, A. F. H., Ibrahim, H. H., Faraj, R. H., Daraei, A. (2020). Strength improvement of expansive soil by utilizing waste glass powder. Case Studies in Construction Materials, 13, e00427. doi: https://doi.org/10.1016/j.cscm.2020.e00427

16. Alqaisi, R. O. (2020). Using eggshell powder as a supplementary additive to lime stabilization in expansive soil. University of Technology Sydney, 138. Available at: http://hdl.handle.net/10453/143865

17. Driss, A. A.-E., Harichane, K., Ghrici, M., Gadouri, H. (2021). Assessing the effect of moulding water content on the behaviour of lime-stabilised an expansive soil. Geomechanics and Geoengineering, 1-13. doi: https://doi.org/10.1080/17486025.2021.1903092

18. Manzanal, D., Orlandi, S., Fernandez, M., Laskowski, C., Barría, J. C., Codevila, M., Piqué, T. (2021). Soil-water retention of highly expansive clay stabilized with a bio-polymer. MATEC Web of Conferences, 337, 01006. doi: https://doi.org/10.1051/ matecconf/202133701006

19. Suresh Reddy, T., Prasad, D. S. V. (2017). Stabilization of Soil Using Sugarcane Straw Ash and Polypropylene Fibres. International Journal of Engineering and Applied Sciences, 4 (6), 5-8. Available at: https://www.neliti.com/id/publications/257450/ stabilization-of-soil-using-sugarcane-straw-ash-and-polypropylene-fibres 